\title{
Isolation of the Galactose-binding Lectin That Mediates the In Vitro Adherence of Entamoeba histolytica
}

\author{
William A. Petri, Jr., Roger D. Smith, „ Paul H. Schlesinger, ${ }^{3}$ Cheryl F. Murphy, and Jonathan I. Ravdin* \\ *Department of Medicine, Divisions of Clinical Pharmacology, Infectious Diseases and Geographic Medicine, University of Virginia, \\ Charlottesville, Virginia 22908; ${ }^{\ddagger}$ Department of Pathology and Laboratory Medicine, University of Cincinnati, Cincinnati, Ohio 45267; \\ and ${ }^{\S}$ Department of Biochemistry, Washington University, St. Louis, Missouri 63110
}

\begin{abstract}
Entamoeba histolytica adheres to human colonic mucus, colonic epithelial cells, and other target cells via a galactose (Gal) or $\boldsymbol{N}$-acetyl-D-galactosamine (GalNAc) inhibitable surface lectin. Blockade of this adherence lectin with Gal or GalNAc in vitro prevents amebic killing of target cells. We have identified and purified the adherence lectin by two methods: affinity columns derivatized with galactose monomers or galactose terminal glycoproteins, and affinity columns and immunoblots prepared with monoclonal antibodies that inhibit amebic adherence. By both methods the adherence lectin was identified as a 170-kD secreted and membrane-bound amebic protein. The surface location of the lectin was confirmed by indirect immunofluorescence. Purified lectin competitively inhibited amebic adherence to target cells by binding to receptors on the target Chinese hamster ovary cells in a Gal-inhibitable manner.
\end{abstract}

\section{Introduction}

The protozoan parasite Entamoeba histolytica is estimated to infect $10 \%$ of the world's population (1). Invasive amebiasis manifests as amebic colitis, which can be complicated by intestinal perforation and peritonitis or hepatic abscess, and results in at least 60,000 deaths worldwide each year (1-3). There is evidence that natural immunity against recurrent invasive amebiasis exists $(3,4)$ but currently no vaccine is available to prevent amebic disease in the developing world. A major thrust of our research is to identify amebic proteins that play a critical role in pathogenesis and to which a host immune response should be directed.

Adherence of $E$. histolytica trophozoites to intestinal mucus, epithelium, and host inflammatory cells occurs before invasion in animal and in vitro models of amebiasis (5-8). A galactose $(\mathrm{Gal})^{1}$ and $N$-acetyl-D-glactosamine (GalNAc) inhibitable surface lectin mediates the adherence of $E$. histolytica trophozoites to Chinese hamster ovary $(\mathrm{CHO})$ cells, certain bacteria, human erythrocytes, and fixed rat and human co-

This paper was presented in part at the National Meeting of the American Federation of Clinical Research, Washington, DC, 1986 and has appeared in abstract form (1986. Clin. Res. 34:529A).

Address correspondence to Jonathan I. Ravdin, M.D., Box 419, School of Medicine, University of Virginia, Charlottesville, VA 22908. 1987.

Received for publication 22 August 1986 and in revised form 5 June

1. Abbreviations used in this paper: ASOR, asialoorosomucoid; $\mathrm{CHO}$ Chinese hamster ovary; Gal, galactose; GalNAc, $N$-acetyl-D-galactosamine.

J. Clin. Invest.

(c) The American Society for Clinical Investigation, Inc.

$0021-9738 / 87 / 11 / 1238 / 07 \quad \$ 2.00$

Volume 80, November 1987, 1238-1244 lonic mucosa (6-9). Inhibition of the lectin with GalNAc blocks the establishment of in vitro adherence and prevents amebae from lysing $\mathrm{CHO}$ cells and human neutrophils (8). Soluble protein preparations from disrupted $E$. histolytica trophozoites contain a galactose- and GalNAc-inhibitable lectin that agglutinates $\mathrm{CHO}$ cells and erythrocytes and is mitogenic for human lymphocytes $(8,9)$. This lectin activity was found to be greater in virulent than avirulent strains of $E$. histolytica in axenic culture (8). We report here the purification of this lectin, its localization to the amebic surface and extracellular medium, and its competitive inhibition of amebic adherence.

\section{Methods}

Cultivation and harvesting of E. histolytica and CHO cells. Axenic $E$. histolytica, strain HM1-IMSS, were grown in medium TYI-S-33 (trypticase yeast extract, iron, and serum) with $100 \mathrm{U} / \mathrm{ml}$ of penicillin and $100 \mu \mathrm{g} / \mathrm{ml}$ of streptomycin sulfate (Pfizer, Inc., New York, NY) (10) at $37^{\circ} \mathrm{C}$ in $250-\mathrm{ml}$ plastic tissue culture flasks. Amebae were harvested after $72 \mathrm{~h}$ of growth by centrifugation at $150 \mathrm{~g}$ for $5 \mathrm{~min}$ at $4^{\circ} \mathrm{C}$ and washed in $75 \mathrm{mM}$ Tris (Sigma Chemical Co., St. Louis, MO) $65 \mathrm{mM} \mathrm{NaCl}, \mathrm{pH} 7.2$ (6). Metabolic labeling with $\left[{ }^{35} \mathrm{~S}\right]$ methionine was accomplished by incubating 1-2 $\times 10^{7}$ trophozoites/ml in TYI-S-33

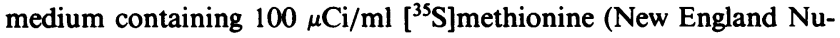
clear, Boston, MA) for $2 \mathrm{~h}$ at $37^{\circ} \mathrm{C}$. $\mathrm{CHO}$ cells were grown in $\mathrm{F} 12$ medium (Gibco, Grand Island, NY) with $10 \%$ fetal bovine serum and $100 \mathrm{U} / \mathrm{ml}$ of penicillin and $100 \mu \mathrm{g} / \mathrm{ml}$ streptomycin sulfate and harvested by trypsinization as described (6).

Adherence of $\mathrm{E}$. histolytica trophozoites to $\mathrm{CHO}$ cells. The measurement of $E$. histolytica trophozoite adherence to $\mathrm{CHO}$ cells was performed as previously described (6). Briefly, amebic trophozoites ( 1 $\left.\times 10^{4}\right)$ and $\mathrm{CHO}$ cells $\left(2 \times 10^{5}\right)$ in the presence or absence of carbohydrate were suspended together at $4^{\circ} \mathrm{C}$ in M199 media (Gibco) containing $25 \mathrm{mM}$ Hepes, pH 6.8 (Sigma Chemical Co.), $5.7 \mathrm{mM}$ cysteine, $0.5 \%$ bovine serum albumin, and $10 \%$ heat-inactivated adult bovine serum (M199s). The trophozoites and $\mathrm{CHO}$ cells were centrifuged together at $150 \mathrm{~g}$ for $5 \mathrm{~min}$ and then incubated at $4^{\circ} \mathrm{C}$ for $2 \mathrm{~h}$. Adherence was measured as the number of amebae having at least three adherent $\mathrm{CHO}$ cells upon vortex resuspension of the cellular pellet with at least 50 amebae counted per tube. Adherence was expressed as the percent of adherence in paired studies performed in control medium (where $60 \%$ of amebae had at least three adherent CHO cells).

Galactose was obtained from Pfanstiehl Laboratories, Waukegan, IL, fetuin (Spiro method) from Gibco, orosomucoid ( $\alpha_{1}$ acid glycoprotein) and asialofetuin from Sigma Chemical Co. Asialoorosomucoid (ASOR) was produced by incubating $5 \mathrm{ml}$ of a $10 \mathrm{mg} / \mathrm{ml}$ solution of orosomucoid in $0.1 \mathrm{M}$ ammonium acetate, $\mathrm{pH} 5.0$, with $1 \mathrm{U}$ of Clostridium perfringens neuraminidase immobilized on agarose beads (Sigma Chemical Co.) for $7 \mathrm{~h}$ at $37^{\circ} \mathrm{C}$ with constant agitation. Neuraminic acid released was $0.4 \mu \mathrm{mol} / \mathrm{mg}$ of orosomucoid as measured by the Warren assay (11). The asialofetuin glycopeptide was prepared from fetuin by the method of Baenziger and Fiete (12).

Affinity chromatography with ASOR and orosomucoid. ASOR and orosomucoid were suspended in $0.1 \mathrm{M}$ sodium bicarbonate and reacted overnight at $4^{\circ} \mathrm{C}$ with Affigel 10 beads (Bio-Rad Laboratories, Richmond, CA) at a ratio of 5-10 $\mathrm{mg}$ protein $/ \mathrm{ml}$ of packed beads 
according to the manufacturer's instructions. The amount of coupling of the protein to the beads varied from 50 to $80 \%$ as assessed by protein assays of the supernatant after coupling by the method of Bradford (13). 1-ml columns of the beads were used for affinity chromatography. Galactose oxidase treatment of the ASOR beads was accomplished by incubating the beads in $10 \mathrm{U} / \mathrm{ml}$ of galactose oxidase for $90 \mathrm{~min}$ at $37^{\circ} \mathrm{C}$.

Amebic trophozoites $\left(1-2 \times 10^{7}\right)$ were metabolically labeled with $\left[{ }^{35} \mathrm{~S}\right]$ methionine and were separated from the culture medium (conditioned medium) by centrifugation at $150 \mathrm{~g}$ for $5 \mathrm{~min}$ and solubilized with $30 \mathrm{mM}$ octylglucoside (Sigma Chemical Co.) The detergent-solubilized amebae and conditioned medium were centrifuged at $250,000 \mathrm{~g}$ for $30 \mathrm{~min}$ at $4^{\circ} \mathrm{C}$ and separately applied to the ASOR-Affigel 10 or orosomucoid-Affigel 10 affinity columns in a column buffer of $50 \mathrm{mM}$ Tris, $200 \mathrm{mM} \mathrm{NaCl}, 10 \mathrm{mM} \mathrm{CaCl}_{2}, \mathrm{pH} 7.35$, at a rate of $10 \mathrm{ml} / \mathrm{h}$. The column was extensively washed with column buffer and fractions collected until no detectable $\left[{ }^{35} \mathrm{~S}\right]$ methionine was washed from the column. The column was then incubated for $30 \mathrm{~min}$ in $0.5 \mathrm{M}$ galactose in column buffer and further fractions collected. The galactose-eluted fractions were analyzed by sodium dodecyl sulfate-polyacrylamide gel electrophoresis (SDS-PAGE).

Affinity chromatography with galactose-silica beads. The galactose affinity column was prepared by derivatizing overnight at $4^{\circ} \mathrm{C} 1 \mathrm{~g}$ of glutaraldehyde-activated silica beads (Boehringer-Mannheim Biochemicals, Indianapolis, IN) with $5 \mathrm{ml}$ of $20 \mathrm{mg} / \mathrm{ml} p$-aminophenyl-1thio- $\beta$-D-galactopyranoside (Sigma Chemical Co.) in $0.1 \mathrm{M}$ bicarbonate, $\mathrm{pH}$ 8.0. Control silica beads were incubated in bicarbonate buffer alone overnight at $4^{\circ} \mathrm{C}$. The silica beads were washed in column buffer (50 mM Tris, $200 \mathrm{mM} \mathrm{NaCl}, 10 \mathrm{mM} \mathrm{CaCl}_{2}, \mathrm{pH} \mathrm{7.35)}$ to remove unbound galactose before the application of $\left[{ }^{35} \mathrm{~S}\right]$ methionine-labeled conditioned medium. The column was washed with column buffer and bound proteins then eluted with $50 \mathrm{mM}$ glycine, $\mathrm{pH} 2.5$.

Affinity chromatography with the H8-5 monoclonal antibody. The mouse H8-5 monoclonal antiamebic antibody was purified from cell culture supernatants on a protein A-agarose column (Sigma Chemical Co.). $5 \mathrm{mg}$ of purified antibody in $2 \mathrm{ml}$ of $0.1 \mathrm{M}$ bicarbonate buffer was bound to Affigel 10 overnight. The column was washed to remove unbound antibody before the application of $\left[{ }^{35} S\right]$ methionine labeled amebic proteins. Amebae were solubilized in $0.1 \%$ Triton $\overline{\mathrm{X}} 100,50$ $\mathrm{mM}$ Tris, $10 \mathrm{mM}$ EDTA, $150 \mathrm{mM} \mathrm{NaCl}, 50 \mathrm{mM} \mathrm{KI}, \mathrm{pH} 8.0$, with insoluble debris removed by centrifugation at $10,000 \mathrm{~g}$ for $10 \mathrm{~min}$ and then applied to the affinity column. After washing the column in the above buffer until no detectable $\left[{ }^{35} \mathrm{~S}\right]$-labeled amebic proteins were detected in the flowthrough, the column was eluted with $50 \mathrm{mM}$ glycine, $\mathrm{pH} 2.5$.

SDS-PAGE and immunoblots. SDS-PAGE was performed by the method of Laemmli (14) using a $10 \%$ acrylamide running gel. Molecular weight determinations were made using high molecular weight standards from Bio-Rad Laboratories or prestained molecular weight standards from Diversified Biotech, Newton Centre, MA. Autoradiography was accomplished by impregnating the gel with Fluoro-Hance (Research Products International Corp., Mount Prospect, IL) and exposing it to Kodak X-Omat AR film for 3 to $5 \mathrm{~d}$ at $-70^{\circ} \mathrm{C}$.

The proteins from the polyacrylamide gels were electrophoretically transferred to $0.1 \mu \mathrm{M}$ pore size nitrocellulose (Schleicher \& Schuell, Keene, $\mathrm{NH}$ ) for immunoblots (15). The excess protein binding capacity of the nitrocellulose was blocked with $5 \%$ nonfat dry milk (Richfood, Richmond, VA) in $50 \mathrm{mM}$ Tris $/ 200 \mathrm{mM} \mathrm{NaCl}, \mathrm{pH}$ 7.5. The nitrocellulose was then incubated overnight at $4^{\circ} \mathrm{C}$ with a $1: 20$ dilution of the F14 mouse monoclonal antibody from cell culture medium in $5 \%$ nonfat dry milk. After washing the nitrocellulose four times for 10 min each with $50 \mathrm{mM}$ Tris $/ 200 \mathrm{mM} \mathrm{NaCl}, \mathrm{pH} 7.5$, it was incubated for $2 \mathrm{~h}$ at $37^{\circ} \mathrm{C}$ with a $1: 1,000$ dilution in $5 \%$ nonfat dry milk of secondary antibody (anti-mouse IgM peroxidase conjugate, Sigma Chemical Co.). The immunoblots were developed with 3,3'-diaminobenzidene after extensive washing.

Indirect immunofluorescence. The monoclonal antibodies (hybridoma cell culture supernatants diluted 1:10) were incubated with 1 $\times 10^{6} / \mathrm{ml}$ live amebic trophozoites at $4^{\circ} \mathrm{C}$ for $1 \mathrm{~h}$ in $\mathrm{M} 199 \mathrm{~s}$. The amebae were washed by pelleting twice in M199s at $150 \mathrm{~g} \times 5 \mathrm{~min}$ and then incubated with a 1:20 dilution of fluorescein isothiocyanate antimouse IgG or IgM (Meloy Labs, Springfield, VA) at $4^{\circ} \mathrm{C}$, washed twice again, and examined under an Axiomat microscope (Carl Zeiss, Inc., Thornwood, NY) by combined phase contrast and epifluorescence.

\section{Results}

Adherence of $E$. histolytica trophozoites to $\mathrm{CHO}$ cells. The adherence of $E$. histolytica trophozoites to CHO cells, which is mediated by the parasite's galactose- and GalNAc-inhibitable surface lectin $(6,8,16)$, was inhibited by galactose terminal asialoglycoproteins at concentrations as low as $0.1 \mu \mathrm{g} / \mathrm{ml}(P$ $<0.01$; Fig. 1). The low molecular weight $(<3 \mathrm{kD})$ asialofetuin glycopeptide $(G P)$ prepared by the method of Baenziger and Fiete contains three terminal galactose residues (12) and was a 10 -fold more potent inhibitor of amebic adherence than galactose monomers. Intact asialofetuin $(A S F)$ with nine terminal galactose residues (12), and ASOR (prepared by neuraminidase treatment of orosomucoid) with 11-16 terminal galactose residues (17), were 1,000 -fold more potent than galactose in inhibiting $E$. histolytica adherence. Fetuin and orosomucoid, in which the galactose residues are concealed by terminal sialic acid residues $(12,17)$, had no effect on amebic adherence when studied at concentrations $(0.01 \mathrm{mg} / \mathrm{ml})$ in which ASF and ASOR were maximally inhibitory (Fig. 1).

ASOR affinity chromatography purification of the amebic adherence lectin. ASOR, the most potent inhibitor of amebic adherence studied, was coupled to a $1-\mathrm{ml}$ column of Affigel 10 for affinity purification of the amebic lectin. Amebic proteins were metabolically labeled with $\left[{ }^{35} S\right]$ methionine with an incorporation of 1-3 dpm/ng protein; conditioned culture medium and octylglucoside-solubilized amebae were separately applied to the ASOR-Affigel 10 affinity column. After extensive washing of the column with application buffer the column was eluted with $0.5 \mathrm{M}$ galactose (Fig. 2) and the peak of $\left[{ }^{35} \mathrm{~S}\right]-$ methionine radioactivity analyzed by SDS-PAGE.

The autoradiograph shown in Fig. 3 demonstrates that a 170-kD metabolically labeled $E$. histolytica protein was eluted by galactose from the ASOR affinity column to which either conditioned medium (lane $A$ ) or octylglucoside-solubilized amebae (lane $C$ ) had been applied. Two minor bands of $\sim 26$ and $30 \mathrm{kD} \mathrm{mol} \mathrm{wt}$ were also detectable. Galactose elution of an orosomucoid-Affigel 10 column to which conditioned me-

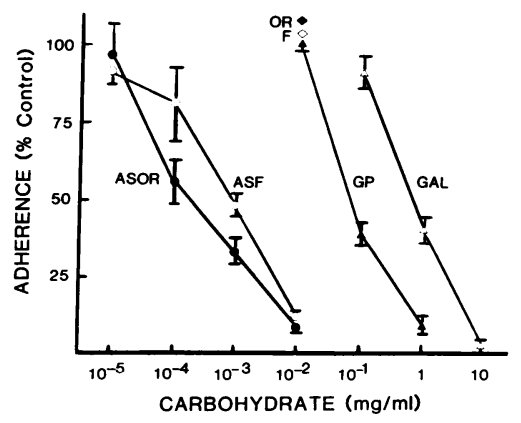

Figure 1. Carbohydrate inhibition of amebic adherence to target cells. Adherence was expressed as percent of adherence in paired studies performed in control medium (where $60 \%$ of amebae had at least three adherent CHO cells upon vortex resuspension of the pellet). Bars are mean $\pm S E$ of 6-11 determinations. Carbohydrate concentrations were determined by phenol-sulfuric acid method (41). (GAL, $\triangle)$ galactose; (GP, $\triangle)$ asialofetuin glycopeptide; $(F, \diamond)$ fetuin; $(O R, \diamond)$ orosomucoid; $(A S F, \circ)$ asialofetuin; $(A S O R, \bullet)$ asialoorosomucoid. 


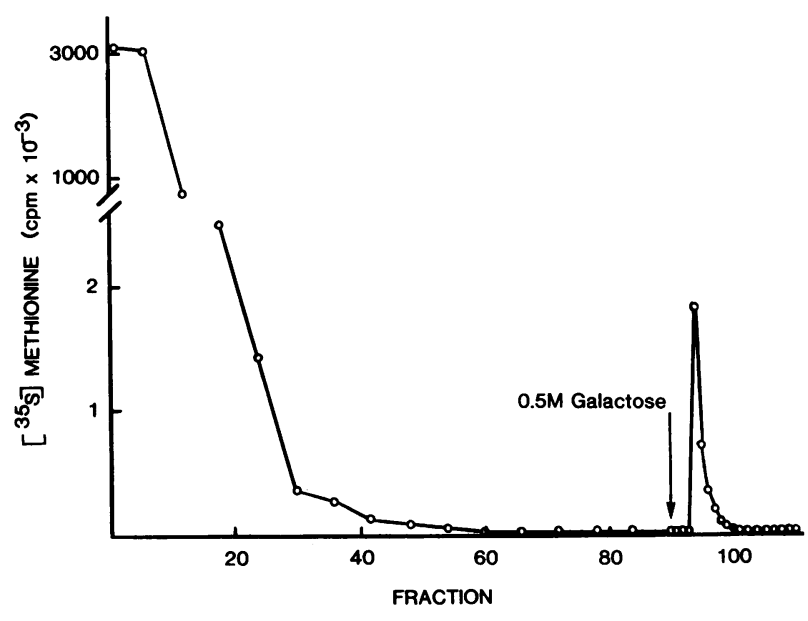

Figure 2. ASOR affinity chromatography purification of the amebic adherence lectin from culture medium. $\left[{ }^{35} \mathrm{~S}\right]$ methionine-labeled amebic proteins in conditioned culture medium were applied to an ASOR-Affigel 10 affinity column and after extensive washing the column was eluted with $0.5 \mathrm{M}$ galactose.

dium had been identically applied did not reveal any radioactive bands (lane $B$ ). Coomassie Blue stained PAGE of the adherence lectin was not significantly different from the autoradiograph of metabolically labeled protein (Fig. 3, insert $D$ ).

The binding of the amebic adherence lectin to the ASOR column was blocked by $0.5 \mathrm{M}$ galactose (Fig. 4 , lane $C$ ) but not by $0.5 \mathrm{M}$ glucose (lane $B$ ). Galactose oxidase treatment of the terminal galactose residues of ASOR also prevented the amebic lectin from binding to the ASOR affinity column, giving further evidence that the amebic adherence lectin was binding to the terminal galactose residues of ASOR (Fig. 5, lanes $H-K)$. The lectin did not bind to a control Affigel 10 column (data not shown).

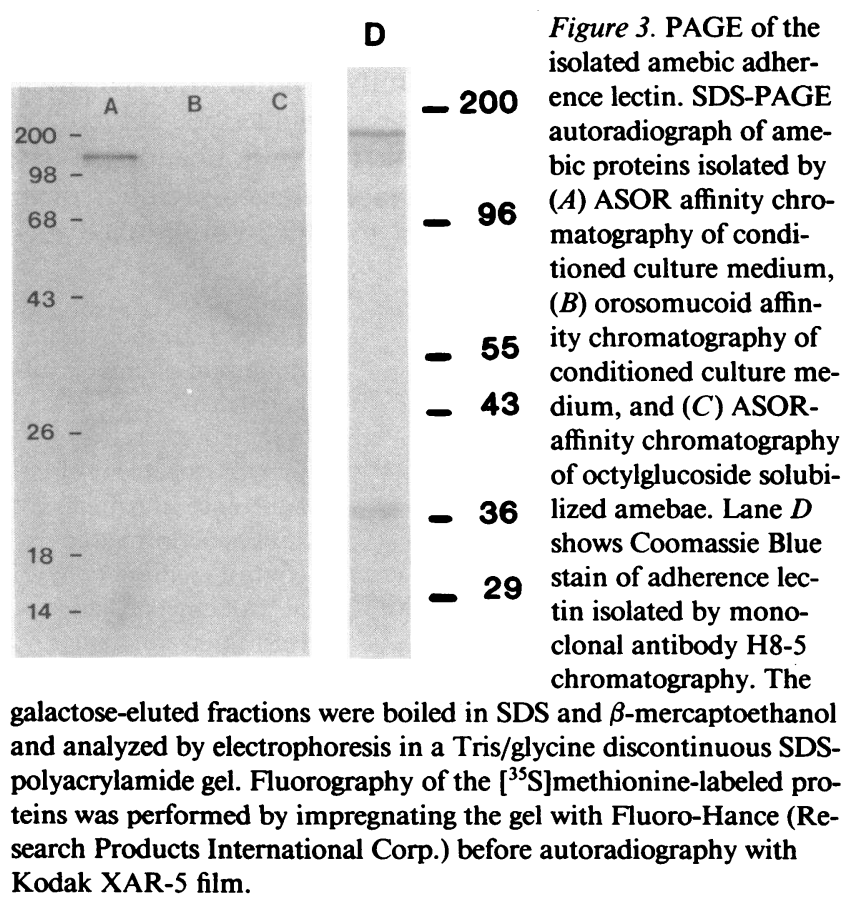

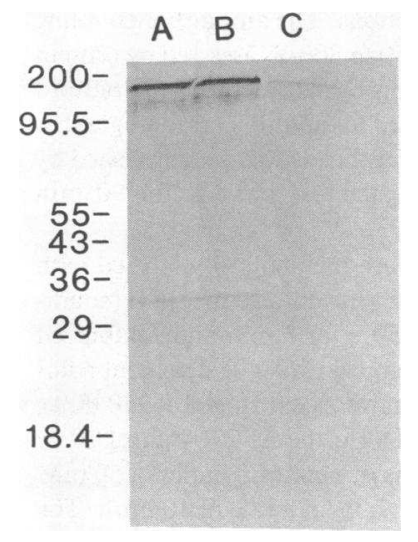

Figure 4. Galactose inhibition of binding of the amebic adherence lectin to the ASOR affinity column. Autoradiograph of SDSPAGE of $\left[{ }^{35}\right.$ S $]$ methionine-labeled amebic proteins eluted with galactose from an ASOR column to which $(A)$ conditioned medium, $(B)$ conditioned medium plus 0.5 $M$ dextrose, or $(C)$ conditioned medium plus $0.5 \mathrm{M}$ galactose had been applied. The columns were extensively washed in $50 \mathrm{mM}$ Tris, $200 \mathrm{mM} \mathrm{NaCl}, 10 \mathrm{mM}$ $\mathrm{CaCl}_{2}, \mathrm{pH} 7.35$, and then eluted with $0.5 \mathrm{M}$ galactose in the above buffer. Galactose-eluted fractions were electrophoresed on $10 \%$ polyacrylamide gels and analyzed by autoradiography.

Galactose affinity chromatography purification of the amebic adherence lectin. The adherence lectin was also successfully purified from conditioned culture medium with an affinity column composed of $p$-aminophenyl-thio- $\beta$-D-galactopyranoside linked to silica beads (Fig. 5, lanes $A-D$ ).

Monoclonal antibody H8-5 affinity chromatography purification of the amebic adherence lectin. The H8-5 antiamebic monoclonal antibody has previously been shown to inhibit amebic adherence (16). Application of $\left[{ }^{35} \mathrm{~S}\right]$ methionine labeled amebic proteins to an affinity column composed of protein A purified H8-5 antibody bound to Affigel 10 resulted in the

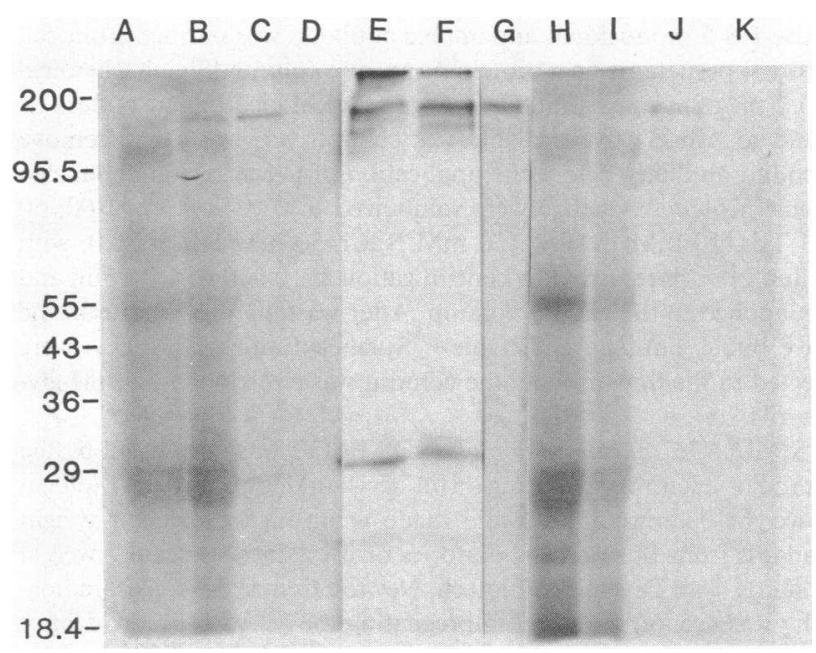

Figure 5. Independent isolation of the 170-kD amebic adherence lectin by affinity chromatography with galactose, ASOR, and H8-5 monoclonal antibody-derivatized affinity columns. SDS-PAGE fluorogram of $(A)\left[{ }^{35} S\right]$ methionine-labeled conditioned culture medium, $(B)$ conditioned medium passed through a $p$-aminophenyl thiogalactopyranoside-silica affinity column, $(C)$ lectin eluted from galactose affinity column, $(D)$ elution of blank silica column to which conditioned medium had been applied, $(E)\left[{ }^{35} S\right]$ methioninelabeled amebae, $(F)$ Triton X-100 solubilized amebae passed through a H8-5 monoclonal antibody-Affigel 10 affinity column, $(G)$ lectin eluted from monoclonal antibody affinity column, $(H)\left[{ }^{35} \mathrm{~S}\right]-$ methionine-labeled conditioned medium, $(I)$ conditioned medium passed through an ASOR-Affigel 10 affinity column, $(J)$ lectin eluted with galactose from ASOR column, $(K)$ elution of galactoseoxidase-treated ASOR column to which conditioned medium had been applied. 
specific elution of a $170-\mathrm{kD}$ protein which comigrated with the adherence lectin purified on the ASOR and galactose affinity columns (Fig. 5, lanes $E-G$ ).

Immunoblots with the F14 adherence-inhibitory monoclonal antibody. Of the several monoclonal antibodies which we have reported that inhibit the adherence of $E$. histolytica trophozoites to CHO cells, only one (F14) recognizes SDS and $\beta$-mercaptoethanol denatured amebic proteins on immunoblots (16). To test whether F14 monoclonal antibody was binding to the same $170-\mathrm{kD}$ amebic protein isolated by the ASOR affinity column, immunoblots (Western blots) were performed. The galactose eluate from the ASOR-Affigel 10 column was subjected to SDS-PAGE and then electrophoretically transferred to nitrocellulose (15). Excess protein binding capacity of the nitrocellulose was blocked with 5\% nonfat dry milk and the nitrocellulose probed with the inhibitory monoclonal antibody. The nitrocellulose was extensively washed before visualizing the bound monoclonal antibodies with an anti-mouse horseradish peroxidase-antibody conjugate.

The immunoblot in Fig. 6 demonstrates that the F14 monoclonal antibody, which inhibited amebic adherence by $86 \%$ (16), recognized the identical $170-\mathrm{kD}$ protein isolated from conditioned culture medium $(A)$ and detergent-solubilized amebae $(B)$ by ASOR affinity chromatography. The minor protein bands at 26 and $30 \mathrm{kD}$ eluted from the ASOR column were not recognized by the F14 monoclonal antibody. As shown in Fig. 7, the F14 monoclonal antibody recognized only the $170-\mathrm{kD}$ protein when whole amebae were immunoblotted as well. A total of three monoclonal antibodies that inhibited amebic adherence recognized the native lectin which was eluted from the H8-5 column and dotted on nitrocellulose (Fig. 8). Three anti-amebic monoclonal antibodies tested which did not inhibit adherence did not bind to the nondenatured lectin. The three adherence-inhibitory monoclonal antibodies bound in a uniform manner to the surface of viable trophozoites at $4^{\circ} \mathrm{C}$ as determined by indirect immunofluorescence and demonstrated capping upon warming to $20^{\circ} \mathrm{C}$ (Fig. 9). No immunofluorescence was observed in the absence of primary antibody or when the D10 monoclonal antibody which does not inhibit amebic adherence was used (data not shown).

Competitive inhibition of amebic adherence to $\mathrm{CHO}$ cells by the purified lectin. To further substantiate that the $170-\mathrm{kD}$ Gal/GalNAc lectin isolated mediates amebic adherence, we determined the ability of lectin purified by H8-5 immunoaf-

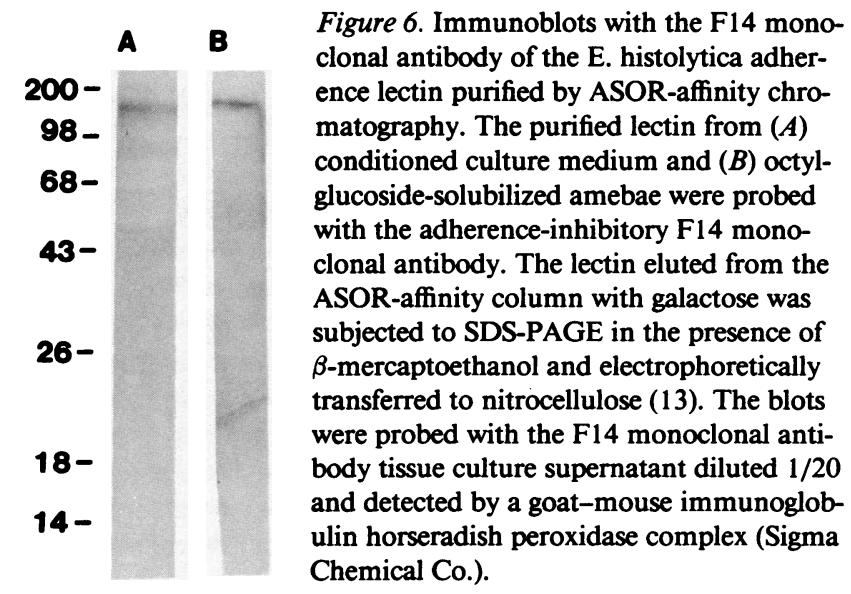

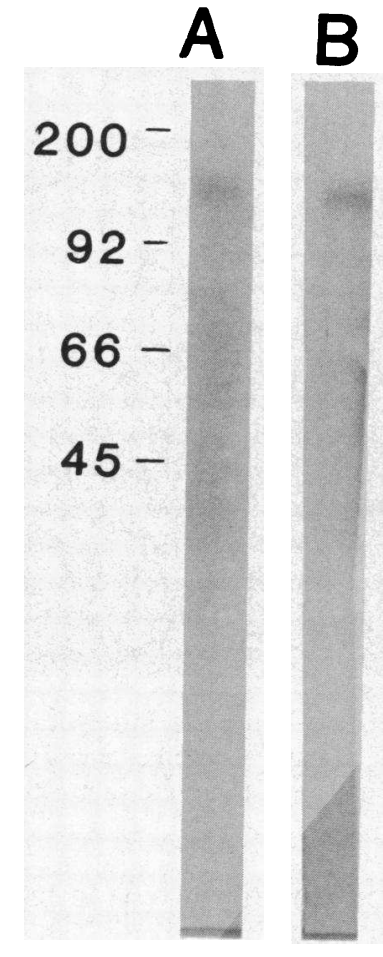

Figure 7. Immunoblots of whole amebae and the purified adherence lectin with the F14 monoclonal antibody. $E$. histolytica trophozoites solubilized in SDS-PAGE sample buffer $(A)$ and lectin purified from conditioned culture medium by ASOR-affinity chromatography $(B)$ were electrophoresed in $10 \%$ polyacrylamide gels and transferred to nitrocellulose. The nitrocellulose was probed with the F14 monoclonal antibody and developed with an anti-mouse immunoglobulin horseradish peroxidase conjugate.

finity chromatography to occupy receptor sites on target cells. $\mathrm{CHO}$ cells were pre-exposed to the purified amebic adherence lectin (0.4-1.6 $\mu \mathrm{g} / 10^{4} \mathrm{CHO}$ cells) for $60 \mathrm{~min}$ on ice and then washed twice before adding amebae and measuring adherence. The adherence lectin significantly inhibited amebic adherence to the pre-exposed $\mathrm{CHO}$ cells in a dose-dependent fashion (Fig. 10). This lectin-mediated inhibition of amebic adherence was blocked by the presence of $0.25 \mathrm{M} \mathrm{Gal}$ or GalNAc but not 0.25 $\mathbf{M}$ dextrose in the preincubation mixture (Table I).

\section{Discussion}

The Gal/GalNAc adherence lectin of $E$. histolytica has been identified as a $170-\mathrm{kD}$ protein independently by adherence-inhibitory monoclonal antibodies and by affinity chromatography with ASOR and galactose, potent inhibitors of amebic adherence. The purified $\mathrm{Gal} / \mathrm{GalNAc}$ adherence lectin retains its biologic activity, competitively inhibiting amebic adherence to $\mathrm{CHO}$ cells in a Gal- or GalNAc-specific fashion. The

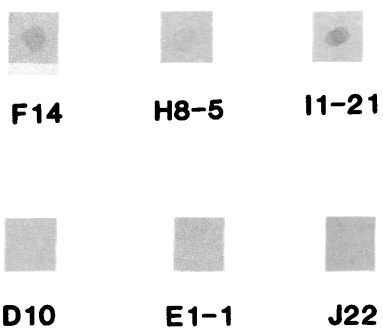

Figure 8. Dot immunoblots of the purified lectin with monoclonal antibodies that inhibit amebic adherence and with control antibodies. Purified amebic lectin $(0.3 \mu \mathrm{g})$ from the H8-5 monoclonal antibody affinity column was dotted on nitrocellulose. The nitrocellulose was blocked with 5\% nonfat dry milk before applying adherence-inhibitory monoclonal anti-

bodies (F14, H8-5, I1-21) or control antiamebic monoclonal antibodies which do not affect adherence (D10, E1-1, J22). Dot blots were developed with an anti-mouse immunoglobulin horseradish peroxidase conjugate. 

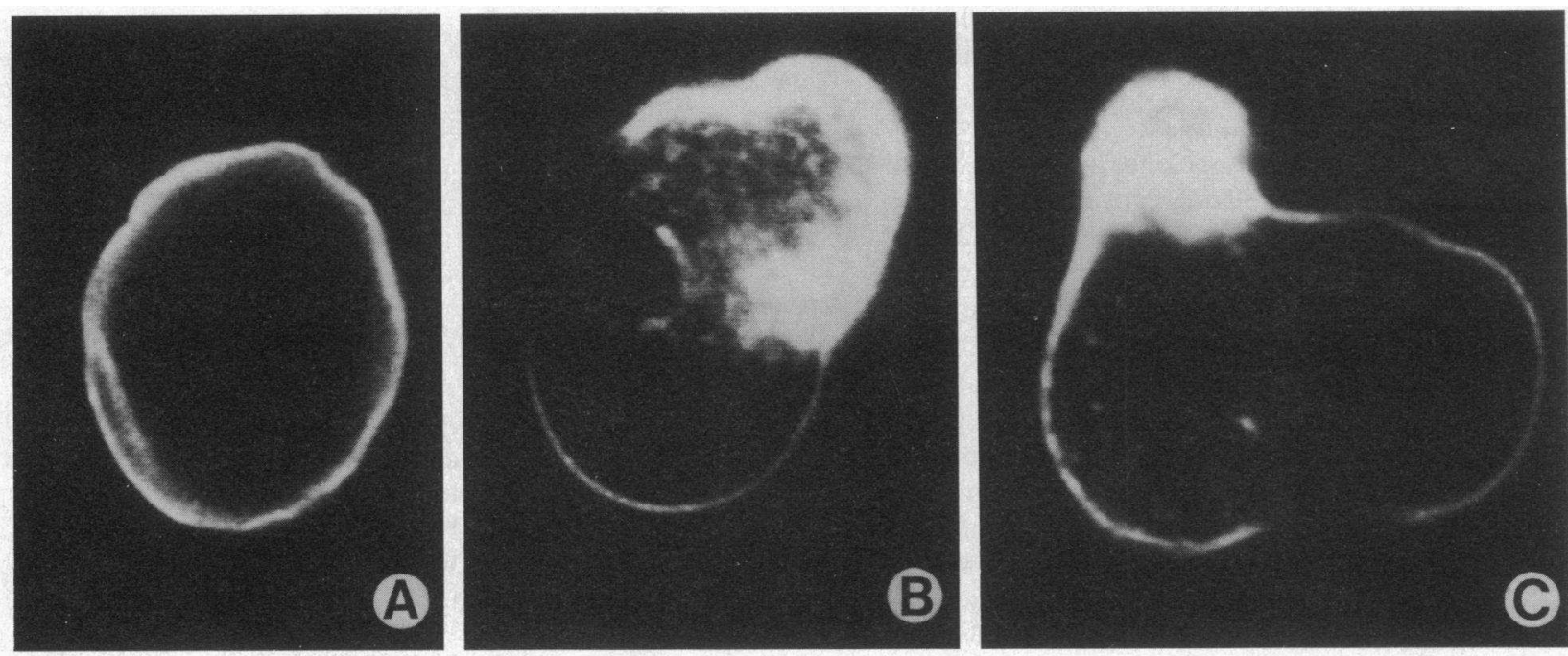

Figure 9. Cell surface capping of the adherence lectin of E. histolytica. Indirect immunofluorescence with the F14 monoclonal antibody was performed at $(A) 4^{\circ} \mathrm{C} ;(B$ and $C) 20^{\circ} \mathrm{C}$ over $5 \mathrm{~min}$. Combined phase contrast and epifluorescence was computer enhanced from a Zeiss Axiomat with a Quantex 9210 image processor using background subtraction, frame averaging, and grey scale expansion.

importance of the indentification of this protein rests in its probable central role in the pathogenesis of amebiasis. The sequence of events in the pathogenesis of invasive amebiasis include intestinal colonization by the parasite, adherence to colonic mucus and host cells, depletion and lysis of the mucus blanket, and disruption of the colonic epithelium accompanied by amebic contact-dependent lysis of host epithelial and inflammatory cells $(5,18)$. Inhibition of the lectin with GalNAc blocks not only amebic adherence to host cells and colonic mucus (7-9; see following companion paper) but also contact-dependent killing of target cells (6-9). GalNAc-mediated inhibition of amebic adherence and cytolytic activity also provides the opportunity for human neutrophils in vitro to kill the trophozoites and limit tissue damage $(9,19)$.

We determined the effect of galactose-terminal asialoglycoproteins on amebic adherence to $\mathrm{CHO}$ cells to identify a high-affinity ligand for subsequent use in purification. Ravdin and Guerrant (6) demonstrated that the simple sugars galac-

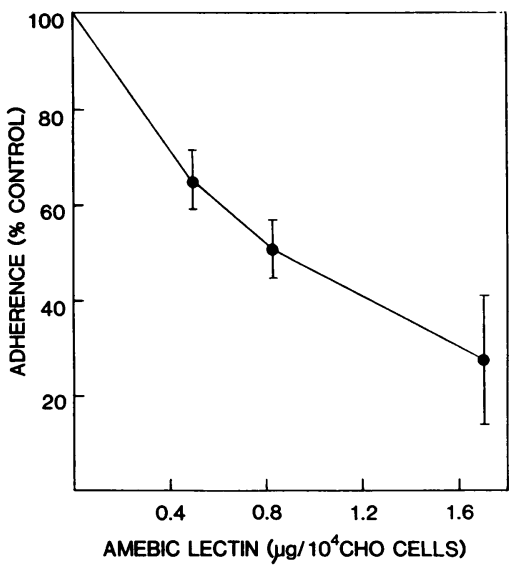

Figure 10. Competitive inhibition of amebic adherence by the purified galactose-binding amebic lectin. $\mathrm{CHO}$ cells in M199s buffer were pretreated for $60 \mathrm{~min}$ on ice with the indicated amounts of the amebic lectin purified by $\mathrm{H} 8-5$ monoclonal antibody affinity chromatography. CHO cells were pelleted and washed twice in M199s after exposure to the lectin and then resuspended with amebic trophozoites at a 20:1 CHO cell/ameba ratio in M199s. The trophozoite-CHO cell mixture was pelleted at $150 \mathrm{~g}$ for $5 \mathrm{~min}$; after $2 \mathrm{~h}$ on ice the pellet was resuspended to measure amebic adherence. Results are expressed as percent of control adherence ( $\overline{\mathrm{x}} \pm \mathrm{SE}, n=3-6)$. tose and GalNAc at concentrations of $10 \mathrm{mg} / \mathrm{ml}$ would completely inhibit amebic adherence to $\mathrm{CHO}$ cells, whereas other sugars such as mannose, neuraminic acid, and $\mathrm{N}$-acetyl glucosamine had no effect. Asialoglycoproteins with multiple terminal galactose residues proved to be much more potent inhibitors of amebic adherence than galactose or GalNAc monomers, with inhibition of adherence seen at concentrations of ASOR as low as $0.1 \mu \mathrm{g} / \mathrm{ml}$. The intact fetuin and orosomucoid molecules, with the galactose residues masked by terminal sialic acid residues, had no effect on amebic adherence and served as important negative controls in these experiments. The greater affinity of the $170-\mathrm{kD} \mathrm{Gal} / \mathrm{GalNAc}$ amebic lectin for galactose terminal glycoproteins is similar to the binding affinities described for the asialoglycoprotein receptor of rabbit liver where, up to a threshold, increasing numbers of terminal galactose residues placed on a neoglycoprotein increased binding avidity (20).

An earlier report from this laboratory (8) utilized Sephacryl S-300 gel filtration chromatography of amebic proteins to partially purify the lectin. The size of the lectin was erroneously estimated to be 43-67 kD in this report because SDS-PAGE of

Table I. Effect of Gal and GalNAc on the Ability of Purified Lectin to Competitively Inhibit Amebic Adherence

\begin{tabular}{ll}
\hline CHO cell preincubation & Adherence \\
\hline & \% of control ${ }^{*}$ \\
$0.5 \mu \mathrm{g}$ lectin & $64.9 \pm 5.8^{\ddagger}$ \\
$0.5 \mu \mathrm{g}$ lectin $+0.25 \mathrm{M}$ dextrose & $59.4 \pm 4.1^{\ddagger}$ \\
$0.5 \mu \mathrm{g}$ lectin $+0.25 \mathrm{M} \mathrm{Gal}$ & $94.9 \pm 2.7$ \\
$0.5 \mu \mathrm{g}^{\prime}$ lectin $+0.25 \mathrm{M}$ GalNAc & $91.0 \pm 4.5$
\end{tabular}

CHO cells $\left(10^{4}\right)$ were preincubated with the purified lectin in the presence or absence of different sugars for $60 \mathrm{~min}$ on ice. CHO cells were then pelleted and washed twice before measuring adherence to amebae. ${ }^{*} \overline{\mathrm{x}} \pm \mathrm{SE}(n=6)$; absolute value for rosette formation in control medium $=50 \% .{ }^{\ddagger} P<0.05$ compared with control or Gal. 
the lectin-containing fractions demonstrated prominent protein bands of 43-67 kD in addition to the $170-\mathrm{kD}$ protein.

One physiologic receptor for the $E$. histolytica adherence lectin is colonic mucus, where amebic trophozoites are found attached before the production of invasive intestinal lesions in humans and animal models (5-8). Human colonic mucus is rich in galactose-terminal glycoproteins (21). Chadee et al. have now demonstrated that purified rat colonic mucin binds specifically to the amebic Gal/GalNAc lectin and that this binding can be inhibited by galactose (see companion paper). Adherence of amebae to colonic mucus may be a prerequisite for successful parasite colonization; a host mucosal antibody response to the Gal/GalNAc lectin has the potential to inhibit intestinal colonization by $E$. histolytica. The association of the Gal/GalNAc lectin with amebic virulence (8) may be analogous to the galactose binding lectins found in Escherichia coli (22) strains that more commonly colonize the urinary tract and cause pyelonephritis (23).

The $E$. histolytica adherence lectin resembles other soluble lectins isolated from vertebrates and cellular slime molds in its specificity for $\beta$-galactosides (24). The existence of membrane and soluble forms of surface antigens has also been seen for the variant surface glycoproteins of trypanosomes where the membrane-bound form has an anchoring phospatidylinositol group (25), and the cellular slime mold-soluble lectin that binds to a galactose-containing receptor on the slime mold surface (26). The biochemical differences and the biologic significance of the membrane-bound and soluble forms of the amebic lectin are under investigation. Whereas the monoclonal antibody and carbohydrate inhibition data presented here demonstrate that the Gal/GalNAc lectin is almost completely responsible for amebic adherence to $\mathrm{CHO}$ cells in our system, other amebic proteins could be involved in amebic adherence to other cells. Recently antibody to a $112-\mathrm{kD}$ protein has been shown to partially inhibit amebic adherence to red blood cells (27).

A lectin is defined as "a sugar-binding protein or glycoprotein of nonimmune origin which agglutinates cells and/or precipitates glycoconjugates" (28). We believe that we are justified in calling the $170-\mathrm{kD}$ adherence protein a lectin by its galactose and GalNac-inhibitable binding to ASOR (Fig. 4) and its mitogenic properties for normal human lymphocytes (29). But it should be noted that we have not rigorously demonstrated its bivalency or polyvalency by cell agglutination or glycoconjugate precipitation assays.

Currently, there is no vaccine available for prevention of invasive amebiasis, the third leading parasitic cause of death worldwide and a source of substantial morbidity in the developing world (1). Patients who have recovered from amebic liver abscess rarely have recurrent invasive amebiasis (4). It thus may be of significance that the $170-\mathrm{kD}$ amebic adherence lectin is recognized on immunoblots by the convalescent sera from patients with amebic liver abscess (30). In animal models, cure of invasive infection or immunization with amebic proteins results in the development of protective immunity $(31-33)$. Present evidence in both humans and animal models indicates that acquired resistance to invasive amebiasis is associated with development of an effective cell-mediated response (33-35). During acute disease in humans there is depression of cell-meditated immunity (36) and Salata et al., using a soluble protein preparation, have demonstrated that patients treated for liver abscess develop antigen-specific lymphocyte-proliferative responses and cytotoxic $T$ cell activity directed against $E$. histolytica trophozoites. Specific antibody production occurs in $95 \%$ of liver abscess patients (37); antibody titers have not correlated with the clinical course (38). Repeated shedding of antiamebic antibodies by viable amebic trophozoites, as we demonstrated with antilectin monoclonal antibody; has been shown to occur by means of a "capping" phenomenon $(39,40)$ that may be protective for the parasite. However, the role of serum or mucosal antibody in host resistance to intestinal colonization by the parasite has not been evaluated. The use of the major amebic adherence protein identified in this report to produce protective immunity in animal models of invasive amebiasis will be the focus of future studies.

\section{Acknowledgments}

We thank Deborah Koons for excellent technical assistance, J. A. Sullivan for performing the indirect immunofluorescence, and Cynthia Kogut for secretarial assistance.

This work was supported in part by a grant to Dr. Petri from the Lucille P. Markey Charitable Trust and grants to Dr. Ravdin from the Thomas F. Jeffress and Kate Miller Jeffress Memorial Trust, the George L. Hartford Foundation, and grant AI-18841 from the National Institute of Allergy and Infectious Diseases: William A. Petri is a Lucille P. Markey Scholar. The Division of Geographic Medicine is supported in part by the Rockefeller Foundation.

\section{References}

1. Walsh, J. A. 1986. Problems in recognition and diagnosis of amebiasis. Estimation of the global magnitude of morbidity and mortality. Rev. Infect. Dis. 8:228-238.

2. Ravdin, J. I., and T. C. Jones. 1984. Entamoeba histolytica. In Principles and Practice of Infectious Diseases. G. L. Mandell, R. G. Douglas, and J. E. Bennett, editors. John Wiley and Sons, New York. 1506-1510.

3. Sepulveda, B., and A. Martinez-Palomo. 1984. Amebiasis: In Tropical and Geographic Medicine. K. S. Warren and A. A. F. Mahmoud, editors. McGraw-Hill Book Co., New York. 305-318.

4. DeLeon, A. 1970. Prognostico tardio en el absceso hepatico amibiano. Arch. Invest. Med. 1:s205-s206.

5. Chadee, K., and E. Meerovitch. 1985. Entamoeba histolytica: early progressive pathology in the cecum of the gerbil (Meriones unguiculatus). Am. J. Trop. Med. Hyg. 34:283-291.

6. Ravdin, J. I., and R. L. Guerrant. 1981. Role of adherence in cytopathogenic mechanisms of Entamoeba histolytica. Study with mammalian tissue culture cells and human erythrocytes. J. Clin. Invest. 68:1305-1313.

7. Bracha, R., and D. Mirelman. 1983. Adherence and ingestion of Escherichia coli serotype 055 by trophozoites of Entamoeba histolytica. Infect. Immun. 40:882-887.

8. Ravdin, J. I., C. F. Murphy, R. A. Salata, R. L. Guerrant, and E. L. Hewlett. 1985. The $N$-acetyl-D-galactosamine inhibitable adherence lectin of Entamoeba histolytica. I. Partial purification and relation to amebic virulence in vitro. J. Infect. Dis. 151:804-815.

9. Salata, R. A., and J. I. Ravdin. 1985. $N$-acetyl-D-galactosamine inhibitable lectin of Entamoeba histolytica. II. Mitogenic activity for human lymphocytes. J. Infect. Dis. 151:812-822.

10. Diamond, L. S., D. R. Harlow, and C. C. Cunnick. 1978. A new medium for axenic cultivation of Entamoeba histolytica and other entamoeba. Trans. Roy. Soc. Trop. Med. Hyg. 72:431-432. 
11. Warren, L. 1959. The thiobarbituric acid assay of sialic acids. J. Biol. Chem. 234:1971-1975.

12. Baenziger, J. U., and D. Fiete. 1979. Structure of the complex olgosaccharides of fetuin. J. Biol. Chem. 254:789-795.

13. Bradford, M. 1976. A rapid and sensitive method for the quantitation of microgram quantities of protein utilizing the principle of protein-dye binding. Anal. Biochem. 72:248-254.

14. Laemmli, U. K. 1970. Cleavage of structural proteins during the assembly of the head of bacteriophage $\mathrm{T}_{4}$. Nature (Lond.). 227:680-685.

15. Towbin, H., T. Stakelin, and J. Gordon. 1979. Electrophoretic transfer of proteins from polyacrylamide gels to nitrocellulose sheets: procedure and some applications. Proc. Natl. Acad. Sci. USA. 76:4350-4354.

16. Ravdin, J. I., W. A. Petri, Jr., C. F. Murphy, and R. D. Smith 1986. Production of mouse monoclonal antibodies which inhibit in vitro adherence of Entamoeba histolytica. Infect. Immun. 53:1-5.

17. Fournet, B., J. Montreuil, G. Strecker, L. Dorland, J. Haverkamp, J. F. G. Vliegenthart, J. P. Binette, and K. Schmid. 1978. Determination of the primary structures of 16 asialocarbohydrate units derived from human plasma $\alpha_{1}$-acid glycoprotein by $360-\mathrm{MHZ}{ }^{1} \mathrm{H}$ NMR spectroscopy and permethylation analysis. Biochemistry. 17:52065214.

18. Ravdin, J. I. 1986. Pathogenesis of disease control by Entamoeba histolytica: studies of adherence, secreted toxins, and contactdependent cytolysis. Rev. Infect. Dis. 8:247-260.

19. Salata, R. A., and J. I. Ravdin. 1986. The interaction of human neutrophils and Entamoeba histolytica increases cytopathogenicity for liver cell monolayers. J. Infect. Dis. 154:19-26.

20. Ashwell, G., and J. Harford. 1982. Carbohydrate-specific receptors of the liver. Ann. Rev. Biochem. 51:531-554.

21. Podolsky, D. 1985. Oligosaccharide structures of isolated human colonic mucin species. J. Biol. Chem. 260:15510-15515.

22. O'Hanley, P., D. Lark, S. Normark, S. Falkow, and G. K. Schoolnick. 1983. Mannose-sensitive and gal-gal binding Escherichia coli pili from recombinant strains. J. Exp. Med. 158:1713-1719.

23. O'Hanley, P., D. Low, I. Romero, D. Lark, K. Vosti, S. Falkow, and G. K. Schoolnick. 1985. Gal-gal binding and hemolysin phenotypes and genotypes associated with uropathogenic Escherichia coli. New Engl. J. Med. 313:414-419.

24. Barondes, S. H. 1984. Soluble lectins: a new class of extracellular proteins. Science (Wash. DC). 223:1259-1264.

25. Ferguson, M. A. J., M. G. Low, and G. A. M. Cross. 1985. Glycosyl-sn-1,2-dimyristylphosphatidylinositol is covalently linked to Trypanosoma brucei variant surface glycoprotein. J. Biol. Chem. 260:14547-14555.

26. Springer, W. R., P. L. Haywood, and S. H. Barondes. 1980. Endogenous cell surface lectin in dictyostelium: quantitation, elution by sugar and elicitation by divalent immunoglobulin. J. Cell Biol. 87:682-690.

27. Arroyo, R., and E. Orozco. 1987. Localization and identifica- tion of an Entamoeba histolytica adhesin. Mol. Biochem. Parasitol. 23:151-158.

28. Goldstein, I. J., R. C. Hughes, M. Monsigny, T. Osawa, and N. Sharon. 1980. What should be called a lectin? Nature (Lond.). 285:66.

29. Petri, W. A., Jr., R. D. Smith, R. A. Salata, and J. I. Ravdin. 1986. Characterization of the membrane and soluble forms of the adherence lectin of Entamoeba histolytica. Program of the 35th Annual Meeting of the American Society of Tropical Medicine and Hygiene. Abstr. 41.

30. Petri, W. A., Jr., M. P. Joyce, J. Broman, R. D. Smith, C. F. Murphy, and R. I. Ravdin. 1987. Recognition of the galactose- or $\mathrm{N}$-acetylgalactosamine-binding lectin of Entamoeba histolytica by human immune sera. Infect. Immun. 55:2327-2331.

31. Sawhey, S., R. N. Chakravarti, P. Jain, and V. K. Vinayak. 1980. Immunogenicity of axenic Entamoeba histolytica antigen and its fractions. Trans. R. Soc. Trop. Med. Hyg. 74:26-29.

32. Vinayak, V. K., P. Jain, and R. N. Chakravarti. 1980. Protective effects of crude and chromatographic fractions of axenic Entamoeba histolytica in guinea pigs. Trans. R. Soc. Trop. Med. Hyg. 74:483-498.

33. Sharma, A., A. Haq, S. Ahmad, and E. Ledere. 1985. Vaccination of rabbits against Entamoeba histolytica with aqueous suspensions of trehalosedimycolate as the adjuvant. Infect. Immun. 48:634637.

34. Ghadirian, E., and E. Meerovitch. 1981. Effect of immunosuppression on the size and metastasis of amoebic liver abscesses in hamsters. Parasitol. Immunol. 3:329-338.

35. Salata, R. A., A. Martinez-Palomo, H. W. Murphy, L. Conales, N. Trevino, E. Segovia, C. F. Murphy, and J. I. Ravdin. 1986. Patients treated for amebic liver abscess develop cell-mediated immune responses effective in vitro against Entamoeba histolytica. J. Immunol. 136:1-7.

36. Ortiz-Ortiz, L., G. Zamacona, B. Sepulveda, and N. R. Capin. 1975. Cell-mediated immunity in patients with amebic abscess of the liver. Clin. Immunol. Immunopathol. 4:127-134.

37. Salata, R. A., and J. I. Ravdin. 1986. Review of the human immune mechanisms directed against Entamoeba histolytica. Rev. In fect. Dis. 8:261-271.

38. Krupp, I. M. 1970. Antibody response in intestinal and extraintestinal amebaisis. Am. J. Trop. Med. Hyg. 19:57-62.

39. Calderon, J., M. De Lourdes Munoz, and H. M. Acosta. 1980. Surface redistribution and release of antibody-induced caps in Entamoeba. J. Exp. Med. 151:185-192.

40. Aust-Kettis, A., and K. G. Sundquist. 1976. Capping in Entamoeba histolytica acceleration and inhibition by experimental procedures. In The Proceedings of the International Conference on Amebiasis. B. Sepulveda and L. Diamond, editors. Instituto Mexicano del Seguro Social, Mexico City. 324-333.

41. Dubois, J., K. A. Gilles, J. K. Hamilton, P. A. Rebers, and F. Smith. 1956. Colorimetric method for determination of sugars and related substances. Anal. Chem. 28:350-356. 